\title{
PERCEPTIONS OF UNIVERSITY AVIATION ASSOCIATION MEMBERS CONCERNING SCHOLARLY WRITING AND PUBLICATION
}

\author{
Henry R. Lehrer, Ph.D. \\ Embry-Riddle Aeronautical University \\ Daytona Beach, FL 32114
}

\begin{abstract}
This research study was an investigation of the perceptions of University Aviation Associations (UAA) members as to the availability and suitability of various publications sources. The publication sources in question were those that are considered by the academic community as scholarly in nature such as textbooks, research reports, journal articles, and manuals. A survey instrument was developed as a data gathering tool for the study. The survey instrument was sent to 106 members of the UAA; seventy-six percent were returned. Questions contained in the survey instrument asked the respondent to indicate the importance of scholarly writing at their institutions, their academic qualifications, and to provide information relative to whether there were sufficient outlets for scholarly writing. The respondents indicated that scholarly writing was important at their institutions and that sufficient publication sources were not available. In addition, respondents indicated that scholarly writing affected decisions on retention, promotion, tenure, and merit.
\end{abstract}

\section{Background}

"It is one of the noblest duties of a university to advance knowledge, and to diffuse it not merely among those who can attend the daily lectures - but far and wide. Daniel Coit Gilman, 1878" (Hawes, 1967, i).

Aeronautical science programs on college and university campuses in all parts of the country have become one of the most demanding and exciting of the new professions. Although established majors have existed on several campuses for many years, it has not been until the past decade that most aviation programs have emerged and become academically viable. However, "...one of the most difficult challenges that we face in collegiate aviation is that of convincing our colleagues in traditional academic disciplines of the academic validity of aviation education" (Isaacson, 1983, p. 6). Additionally, as collegiate aviation programs have grown, matured, and achieved increased visibility and vitality in academe, concerns have been expressed by certain accreditation associations as to the academic viability of such egalitarian programs.

A closely related component of the same concern appears to be the scholarly productivity of aviation faculty members at some institutions. The traditional collegiate benchmarks for faculty employment, retention, merit, and promotion have changed little over the years. The three areas most often considered in such decisions are teaching, service, and scholarly productivity in the form of research and writing. A common metaphor relative to the importance of scholarly productivity has been simply "publish or perish." However, the sole act of authorship is often not the primary question; the key component appears to be publishing in both a refereed journal and in the appropriate discipline. Schultz (1987) stated 
that it is not simply a matter of publication, but of the publication in refereed journals in the author's academic field.

\section{The Publishing Chore}

An author of aviation related scholarly work centered on collegiate subject areas who wishes to submit a manuscript to a refereed publications must do so in a rather tangential manner. A proven methodology might include submission to the Journal of Epsilon Pi Tau, The Technology Teacher, The Transportation Journal, The Transportation Quarterly or another publication that serves a technologically oriented audience. Several of these publications have a policy of using the preferred blind peer review method of evaluating manuscripts. However, there is no specific vehicle for the refereed publication of monographs, articles, research findings, or the results of other scholarly activity that is specifically identified as serving the unique subject area represented by higher education aviation activities.

The need to establish a refereed journal for the publication of scholarly work in collegiate aviation has become a concern with the profession. The University Aviation Association (UAA) has until this time played an important but solitary role in bringing academic integrity to college and university aviation programs.

The UAA has engaged in this mission through the activity of the Publications Committee of the Association. However, the sole committee activity to date, in the form of a referee review process, has been the annual preparation of the Proceedings of the Fall Educational Conference. While this effort has provided numerous authors with an opportunity to share new knowledge with the profession, the endeavor has not been a totally satisfactory solution to the problem of publication in the field. A "...major limitation facing all our aviation faculty in the past has been the lack of a suitable journal for the publication of papers and professional articles" (Kiteley, 1983, p. 3).

\section{UAA Membership Survey}

A number of questions were to be answered by this research project. The survey instrument used as a data gathering instrument sought to determine whether scholarly writing was important at the respondent's institution and what specific type of activity was most important. Additionally, the survey sought to directly determine whether sufficient publication sources were available and to indirectly determine whether a scholarly journal dedicated to the field of collegiate aviation should be established.

\section{Subjects}

The subjects for the study were professional and honorary members of the University Aviation Association. Professional members are those persons that are actively engaged in collegiate aviation activities and honorary members are those persons who have recently retired from active teaching. The subjects were selected from the UAA Membership List (University Aviation Association, 1988) which contained names of approximately 202 professional and honorary members. This study used a sample size of over $50 \%$ which is consistent with Bartz (1981) who stated that "...all other things being equal, a sample is more 
likely to be accurate as it increases in size" (p. 151). There were 31 states and the District of Columbia represented among those selected. States that were not selected did not have a professional or honorary member listed on the UAA Membership List (University Aviation Association, 1988).

\section{Survey Instrument}

The survey instrument used for this study had two sections. The first section solicited responses concerning the respondent's institution, degree(s), academic rank, position, employment status, years with their present institution, and the number of years in higher education. The second section contained the survey questions concerning scholarly writing.

A survey packet containing a cover letter, the survey instrument, and a stamped return envelope were mailed to the selected participants. The cover letter informed the potential respondent about the study and instructed them to return the completed survey in the enclosed stamped envelope. If the person did not wish to participate, they were instructed to return the unanswered survey in the enclosed stamped envelope.

\section{Demographic Data}

The survey instrument was sent to 106 of the 205 professional and honorary members of the University Aviation Association. Of those 106, a total of 81 or $76.4 \%$ were returned. The information in Table 1 reports whether the respondent was associated with a private or

Table 1

Characteristics of Respondent's Institutions

\begin{tabular}{llll}
\hline Enrollment & Private & Public & Total \\
\hline Under 5000 & $13(16.0)$ & $12(14.8)$ & $25(30.9)$ \\
$5000-10000$ & $05(06.2)$ & $11(13.6)$ & $16(19.8)$ \\
$10000-20000$ & $02(02.5)$ & $15(18.5)$ & $17(21.0)$ \\
Over 20000 & $00(00.0)$ & $23(28.4)$ & $23(28.4)$ \\
Total & $20(24.7)$ & $61(75.3)$ & $81(100.0)$ \\
\end{tabular}

Note: All numbers in parenthesis are percentages.

public educational institution and the size of the undergraduate enrollment at that school. Of the 81 respondents, 61 or $75.3 \%$ were from public institutions and 20 or $24.7 \%$ were at private schools. Twenty-five or $30.9 \%$ of the respondents were associated with schools that had an undergraduate enrollment of under 5000 . Twenty or $24.7 \%$ were from schools that were public institutions with an enrollment of over 20000 undergraduate students. 
The information contained in Table 2 reports the highest degree awarded at the respondent's institution. The master was the highest degree awarded at eight of 20 private

Table 2

Respondent's Institution and Highest Degree Awarded

\begin{tabular}{llll}
\hline \multicolumn{1}{c}{ Highest Degree } & Private & Public & Total \\
\hline Associate & $00(00.0)$ & $13(16.0)$ & $13(16.0)$ \\
Bachelor & $06(07.4)$ & $04(04.9)$ & $10(12.3)$ \\
Master & $08(09.9)$ & $17(21.0)$ & $25(30.9)$ \\
Doctorate & $06(07.4)$ & $27(33.3)$ & $33(40.7)$ \\
$\quad$ Total & $20(24.7)$ & $61(75.3)$ & $81(100.0)$ \\
\end{tabular}

institutions. The doctorate was the highest degree awarded at 27 of 61 public institutions and 58 of 81 schools awarded an advanced degree. Only public institutions granted associate degrees.

Information about the employment track of the respondents is contained in Table 3 . The respondent could be tenured, on a tenure track, on in a position that did not culminate in tenure. The largest group of respondents were tenured with forty-five or $55.6 \%$ represented.

Table 3

Respondent's Employment Track

\begin{tabular}{llll}
\hline \multicolumn{1}{c}{ Track } & Private & Public & Total \\
& & & \\
\hline & & & \\
Tenured & $04(04.9)$ & $41(50.6)$ & $45(55.6)$ \\
On Tenure Track & $05(06.2)$ & $07(08.6)$ & $12(14.8)$ \\
Non-Tenure Track & $07(08.6)$ & $12(14.8)$ & $19(23.5)$ \\
Missing Data & $04(04.9)$ & $01(01.2)$ & $05(06.2)$ \\
$\quad$ Total & $20(24.7)$ & $61(75.3)$ & $81(100.0)$ \\
\end{tabular}

Twelve or $14.8 \%$ of the respondents were on a tenure track and 19 or $23.5 \%$ of the respondents were in positions that did not culminate in tenure.

Table 4 reports information concerning the respondent's rank and position. In cases of more than one category being indicated, the lower of the two is reported. Twenty-six of the respondents indicated that their primary duty was as faculty members. Fifty-five respondents had some type of administrative responsibility; one respondent is a vice-president. 
Table 4

Respondent's Academic Rank and Position

\begin{tabular}{|c|c|c|c|c|c|c|}
\hline Rank & Fac. & Chair & Dir. & Dean & VP & Total \\
\hline Specialist & 02 & 02 & 00 & 00 & 00 & 04 \\
\hline $\begin{array}{l}\text { Instructor } \\
\text { Assistant }\end{array}$ & 03 & 02 & 01 & 00 & 00 & 06 \\
\hline $\begin{array}{l}\text { Professor } \\
\text { Associate }\end{array}$ & 09 & 06 & 02 & 00 & 00 & 17 \\
\hline Professor & 09 & 10 & 03 & 00 & 00 & 22 \\
\hline Professor & 02 & 15 & 02 & 07 & 01 & 27 \\
\hline Missing Data & 01 & 00 & 02 & 02 & 00 & 05 \\
\hline Total & 26 & 35 & 10 & 09 & 01 & 81 \\
\hline
\end{tabular}

Eleven of the faculty respondents held senior faculty rank of Associate Professor or Professor and twenty-five of the thirty-five chairpersons were Associate Professor or Professor.

Table 5 reports the academic rank of the respondents and their highest degree. Five of the eight respondents with a Bachelor's degree as their highest degree indicated that they held the rank of Instructor or Assistant Professor.

Table 5

Respondent's Academic Rank and Highest Degree

\begin{tabular}{lllll}
\hline & Bachelor & Master & Doctorate & Total \\
Rank & & & & \\
\hline Specialist & $01(01.2)$ & $03(03.7)$ & $00(00.0)$ & $04(04.9)$ \\
$\begin{array}{l}\text { Instructor } \\
\text { Assistant }\end{array}$ & $03(03.7)$ & $03(03.7)$ & $00(00.0)$ & $06(07.4)$ \\
$\begin{array}{l}\text { Professor } \\
\text { Associate }\end{array}$ & $02(02.5)$ & $11(13.6)$ & $04(04.9)$ & $17(21.0)$ \\
$\begin{array}{c}\text { Professor } \\
\text { Professor }\end{array}$ & $01(01.2)$ & $12(14.8)$ & $09(11.1)$ & $22(27.2)$ \\
Missing Data & $00(00.0)$ & $03(03.7)$ & $03(03.7)$ & $06(07.4)$ \\
Total & $08(09.9)$ & $39(48.1)$ & $34(42.0)$ & $81(100.0)$ \\
\hline
\end{tabular}


Twenty-three of 36 respondents with a Master's degree as their highest degree indicated that they held the rank of Assistant or Associate Professor. Of those respondents that had the Doctorate, 27 of 31 held the rank of Associate Professor or Professor. Of all respondents, 48 of 81 held the rank of Associate Professor or Professor.

The information in Table 6 reports the respondent's years in higher education and the number of years with their current educational institution. Four of the respondents had been with their present institution less than three years and in higher education a like interval. Ten

Table 6

Respondent's Years of Experience in Higher Education

Years with Current Institution

$$
<3 \quad 3-5 \quad 5-10>10
$$

Years in Higher

Education Total

\begin{tabular}{llllll}
$<3$ & 04 & 00 & 00 & 00 & 04 \\
$3-5$ & 03 & 03 & 00 & 00 & 06 \\
$5-10$ & 03 & 01 & 10 & 00 & 14 \\
$>10$ & 06 & 00 & 07 & 44 & 57 \\
$\quad$ Total & 16 & 04 & 17 & 44 & 81 \\
\hline
\end{tabular}

respondents had between five and ten years in both higher education and with their current institution. Forty-four respondents indicated that they had over 10 years experience in higher education as well as with their present institution.

\section{Opinion Questions}

The following data pertain to the questions on the survey instrument that solicit responses concerning the importance of scholarly writing. A five point Likert scale was utilized for all responses in this section.

Of particular interest in the following section was whether specific groups of respondents answered differently. The difference to be tested was whether survey responses were dependent on the participant's academic rank, employment track, position, and highest degree. The null hypothesis to be tested was that there was no significant differences in how a survey participant responded as a function of the four variables stated above. The hypothesis was tested by using the cross-tabulation function of the Abstat Statistical Program with an IBM AT Computer for goodness of fit using the Chi Square Distribution; the level of significance was set at .05 . Selection of this non-parametric test as appropriate was based 
on the fact that use of a Likert scale for opinion responses on the survey instrument yielded nominal data.

The test of significance for the responses to the opinion questions below indicated that the null hypothesis was accepted for most of the responses. There were thirty-two separate tests of significance and in all but eight, the calculated value of Chi Square was less than the critical value. In six of the eight tests in which the calculated value for Chi Square exceeded the critical value, a closer analysis supported the conclusion that sampling error was present. This sampling error appeared to be due to the large number of cells, in some cases over $40 \%$ within each separate test, that had either one response or none within that cell. The two cases where a significant difference in the manner in which the participants responded will be discussed later.

Table 7 contains the responses of the survey participants to the questions of their ranking of scholarly writing importance. Each persons was asked to indicate which of the five different activities was ranked as 1 - Most Important to 5 - Least Important. The specific activities were a research grant and the associated final report, an article in a non-refereed magazine or journal, the preparation of a departmental manual, the authoring of a text, or article in a refereed publication.

Thirty-three or $43 \%$ of the respondents ranked authoring a textbook as Most Important and 25 or $32 \%$ ranked a grant and the final report as Most Important. However, in a summary of

Table 7

Importance of Various Scholarly Writing

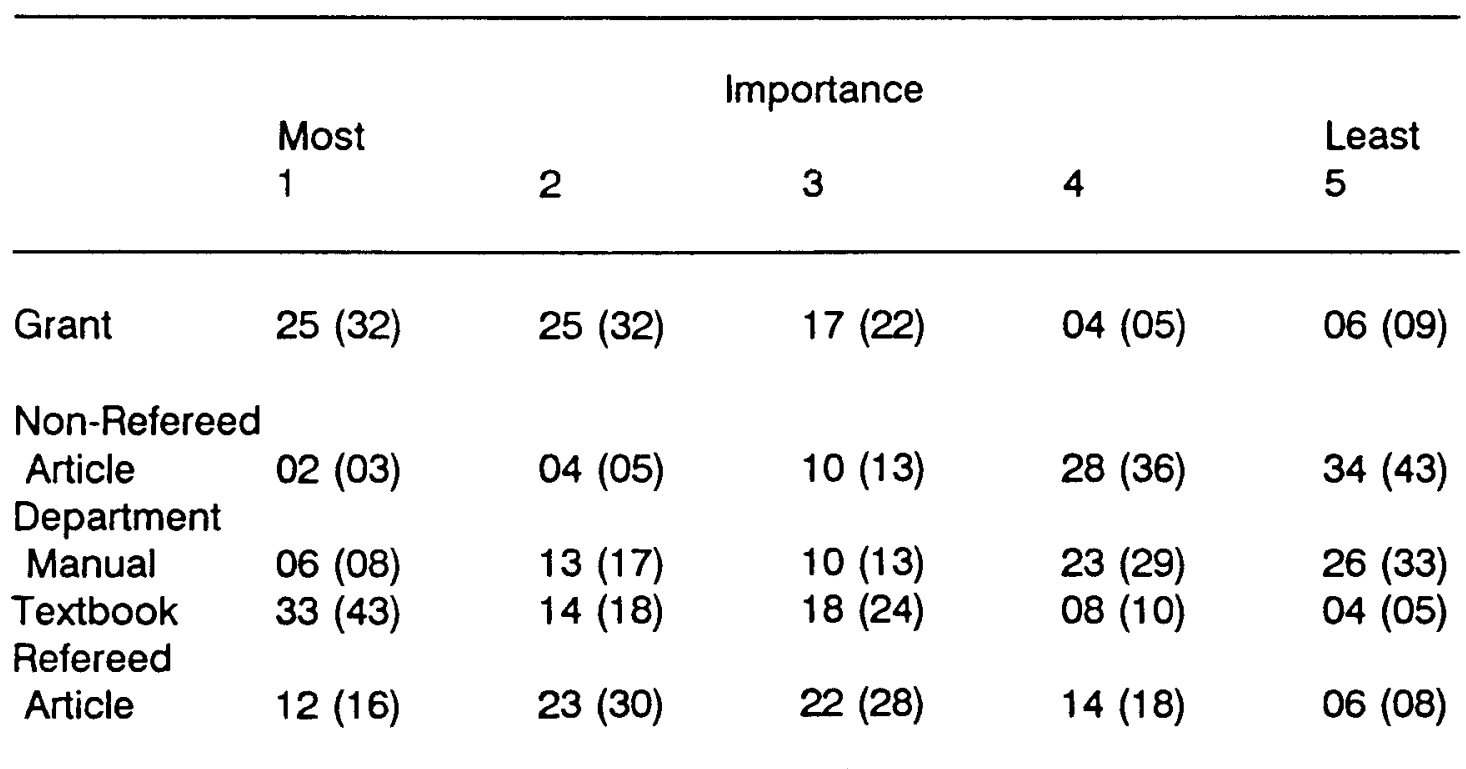

responses 1 and 2, 50 or $64 \%$ ranked a grant as very important and 47 or $61 \%$ ranked a textbook as very important. 
An article in a refereed journal was ranked by 12 or $16 \%$ as Most Important or as Most Important and Somewhat Less Important by 35 or $46 \%$ of the respondents. A department manual was ranked as Least Important by 26 or $33 \%$ of the respondents and an article in a non-refereed journal as ranked Least Important by 34 or $43 \%$ of the respondents.

Table 8 reports information about three of the nine additional survey questions of the study. Six questions from this section have been omitted was being inappropriate for this report. Respondents were asked to respond to each question by indicating 1 - Strongly

Table 8

Opinion Questions

\begin{tabular}{lllll}
\hline $\begin{array}{l}\text { Strongly } \\
\text { Disagree }\end{array}$ & Disagree & Neutral & Agree & $\begin{array}{l}\text { Strongly } \\
\text { Agree }\end{array}$ \\
1 & 2 & 3 & 4 & 5 \\
\hline
\end{tabular}

Scholarly Productivity in the form of writing is important at my institution
07 (09)
$08(10)$
$14(17)$
$20(25)$
$32(39)$

Scholarly productivity in the form of writing affects decisions on retention, promotion tenure, and merit.
$06(07)$
$12(15)$
$12(15)$
$24(30)$
$27(33)$

There are a sufficient number of publication sources in aviation education.
$25(31)$
$29(36)$
$15(18)$
$08(10)$
$04(05)$

Disagree, 2 - Disagree, 3 - Neutral, 4 - Agree, and 5 - Strongly Agree. Fifty-two or 64\% Agreed or Strongly Agreed that scholarly writing was important at their institution. Fifty-one or $63 \%$ of the respondents Agreed or Strongly Agreed that scholarly productivity affected decisions on retention, promotion, tenure, and merit.

Fifty-four or $67 \%$ of the respondents Disagree or Strongly Disagreed that there are a sufficient number of publication sources in collegiate aviation. However, it should be noted that there was some disagreement among the respondents to this questions as a function of their employment track. Eleven of the twelve respondents that did not have tenure and were on a tenure track felt that Disagreed or Strongly Disagreed that there were sufficient publication sources. Those individuals in a non tenured position offered a wide range of responses to this question. There was also some disagreement among the participants with different academic degrees to this same question. Individuals with their highest degree a 
Bachelor's degree were somewhat neutral in their response but those with Master's or Doctorates indicated that they Disagreed or Strongly Disagreed with the number of publication sources. This difference may be a result of the small number, eight or $9.9 \%$, of the respondents with only a Bachelor's degree.

\section{Conclusions}

The profile for the UAA respondent for this study was a tenured department chair with a Master's degree at a public institution with less than a 5000 student undergraduate enrollment. That person was an Associate Professor or Professor, had over 10 years experience at that institution, and the highest degree granted at their school was a Doctorate. Although this profile can not be generalized to the entire population, it appears that it may be the norm because all percentages approached or exceeded $50 \%$.

The respondents indicated that grant writing and the authoring of textbooks were the most important scholarly writing. However, the publication of an article in a refereed journal was also considered as important. The respondents stated that scholarly writing was becoming more important at their schools in matters of retention, tenure, merit, and promotion as well as showing a preference toward refereed over non-refereed publication. The respondents also indicated that there were not a sufficient number of publication sources in collegiate aviation.

Scholarly productivity in the form of writing appears to be as important as ever on the college campus, however, the traditional form of grant writing and the associated research reports and textbook authorship may need to be supplemented. A scholarly refereed journal may be needed in collegiate aviation. The respondents in the survey indicated support for this form of publication. The UAA or a university may wish to undertake this task; it may be very important to the membership in the future.

There is additional interest in the establishment of a refereed journal among persons associated with aviation in other than a teaching and/or research capacity. Hamilton (1987) stated that it is firmly believed "...that a professional journal (Journal of Aviation Education) could both reflect and contribute to the increasing professionalism of aviation education within institutions of higher learning" (p. 6).

Perhaps the argument that best captures the need for a scholarly journal in collegiate aviation was voiced by UAA President Hemphill (1988) in the University Aviation Association Newsletter. He stated that the need for such a publication "...would provide a forum and greatly expand the opportunities for refereed publication .... and stimulate academic interaction among our members which will strengthen and bond our unity (p. 1). 


\section{References}

Bartz, A. (1981). Basic statistical concepts (2nd ed.). Moorhead, MN: Burgess.

Gay, L. (1981). Educational research (2nd ed.). Columbus, OH: Charles E. Merrill.

Hamilton, J. (1987, June/July). In support of establishment of a refereed journal [Letters to the editor]. University Aviation Association Newsletter, p. 6.

Hawes, G. (1967). To advance knowledge. New York: Association of University Presses.

Hemphill, W. (1988, June/July). University Aviation Association Newsletter. (Available from [University Aviation Association, Opelika, AL 36801])

Isaacson, H. (1983, February/March). University Aviation Association Newsletter. (Available from [University Aviation Association, Opelika, AL 36801])

Kiteley, G. (1983, August/September). University Aviation Association Newsletter. (Available from [University Aviation Association, Opelika, AL 36801])

Schultz, J. (1987, April/May). University Aviation Association Newsletter. (Available from [University Aviation Association, Opelika, AL 36801])

University Aviation Association (1988). UAA membership list. Opelika, AL: Author. 